\title{
The in vitro determination of the protein quality of rumen microorganisms of cows on urea-rich feed
}

\author{
Eeva-Liisa Syväoja and Matti Kreula \\ Biochemical Research Institute, Kalevankatu 56 B, 00180 Helsinki 18, Finland
}

\begin{abstract}
The amino acid composition, essential amino acid index (EAA-I), pepsinpancreatin in vitro digestibility and pepsin-pancreatin-digest-residue-index (PPDR-I)of the rumen bacterial and protozoal protein of cows fed urea and ammonium salts as their sole source of nitrogen (0-cows) or as a partial source (ULP-cows), and of cows on normal protein-rich feed (NorP-cows), were determined.

The amino acid compositions of the rumen bacteria showed very slight changes even though the diets were very different. The amino acid compositions of the pure bacterial strains isolated from the rumina differed slightly.

The amino acid compositions of the rumen protozoa of the ULP- and NorP-cows differed only with respect to isoleucine and tyrosine. Protozoa could be found only occasionally in the rumen of the 0 -cow, there being only two species. Their nutritional significance was obviously very small.

When the nutritional quality of the microbial protein was studied on the basis of its amino acid composition it was found that the EAA-I of bacteria did not differ sig'nificantly. Neither did the EAA-I of protozoa differ.

The pepsin-pancreatin in vitro digestibility of protozoa was higher on all the feeds than that of bacteria. The rumen bacterial in vitro digestibility with 0 -cows differed from that of the ULP-samples but not from that of the NorP-samples. The digestibility of single amino acids, with the exception of diaminopimelic acid, glycine and alanine, did not differ from the digestibility of the total amino acids. The much larger number of bacteria in the rumen of 0 -cows compared with those of ULP- and NorPcows compensates in this way for the lower digestibility of bacterial protein in 0-cows. The PPDR-I of both bacteria and protozoa were well correlated with the in vitro digestibility.
\end{abstract}

\section{Introduction}

The requirement for and utilisation of feed nitrogen by ruminants depends on both the source of energy and the intake of digestible energy. Since the consumption of energy is limited, it is very possible that the amount of protein required for the daily production of milk and meat is larger than the amount of protein synthesised in the rumen. The active microbial population in the rumen decomposes the fodder to absorbable nutrients. Urea is decomposed to ammonia by the action of urease enzyme. It is assumed that on average $70 \%$ of the crude protein of the feed given to the ruminant is decomposed to am- 
monia in the rumen. Only about $30 \%$ is transferred undecomposed through the rumen. Depending on the intake of energy and its quality, ammonia is used to form bacterial protein. It is estimated that $80 \%$ of the rumen bacteria are able to use ammonia as their sole source of nitrogen. Some even prefer ammonia to amino acids. Therefore microbial protein is a very important protein store for the cow.

On a feed in which urea and ammonium salts are the sole source of nitrogen (VIRTANEN 1963, 1966), microbial protein is the only source of protein for the host animal, with the exception of the recycled protein formed in the saliva, which has also been derived from urea. Although such cows do not receive proteins in their feed, the protein of their milk has a composition similar to that of the milk of cows on a normal, protein-containing feed (SyväoJA 1971). However, the amount of milk produced by these cows is about $1000-2000$ $\mathrm{kg}$ smaller than that of cows which receive part of their nitrogen requirement from natural feed. Also the annual production of the total protein is smaller (Virtanen 1966, 1967, Ettala and Kreula 1976).

By changing the feed it is possible to change the microbial population of the rumen (Hungate 1965, WARNER 1965). The amino acid compositions of the microbial population show rather small differences on very different feeds (Weller 1957, Purser and Buechler 1966, Bergen 1967, Williams and Dinusson 1973).

The similarity of the amino acid compositions of acid-hydrolysed microbial preparations does not mean, however, that the rumen microorganisms would have the same value with respect to protein quality. Their digestibility may either be totally different, or may differ only with respect to certain amino acids on different protein feeds.

The present paper reports a study of the amino acid composition and the in vitro digestibility of the protein, digested with pepsin and pancreatin, of the rumen microorganisms of cows fed urea and ammonium salts as a sole source of nitrogen ( 0 -feed) or as a partial source of nitrogen (ULP-feed) and of cows on normal protein-rich feed (NorP-feed).

\section{Materials and Methods}

The rumen fluid samples of the cows (0-cows) which had received purified carbohydrates as their energy source and urea and ammonium salts as their sole nitrogen source and of cows which had received small amounts of protein and large amounts of urea as their nitrogen source (ULP-cows) were collected through a fistula. Detailed information about the feed and production of these cows has been published previously (Virtanen 1966, 1967, Virtanen et al. 1972, Ettala and Kreula 1976.) Rumen fluid samples from one 0-cow and from cows on normal protein feed (NorP-cows) were obtained immediately after slaughter.

The rumen fluid samples were filtered through glassfibre cloth in order to remove large feed particles. The protozoa were separated from the rumen fluid by centrifugation at $100 \mathrm{rpm}$ for $10 \mathrm{~min}$, placed in a separating funnel containing $0.1 \mathrm{M}$ phosphate buffer $(\mathrm{pH}$ 7.0) and were allowed to sediment. 
After a few minutes the light protozoal deposit at the bottom was collected and the washing with phosphate buffer repeated. The homogenous protozoal mass was lyophilized. The rumen fluid from which the protozoa had been removed was further centrifuged at $500 \mathrm{xg}$ for $10 \mathrm{~min}$, when feed particles could be removed. The supernatant was further centrifuged at $28500 \mathrm{x} g$ for $20 \mathrm{~min}$. The bacterial precipitate was then washed thrice with the phosphate buffer and once with water. After the last centrifugation the bacteria were mixed to homogeneity with water and lyophilised. The microbial preparations were stored at $-18^{\circ} \mathrm{C}$. Nitrogen determinations were performed by the Kjeldahl method using selenium as the catalyst.

Using rumen fluid samples from one 0 -cow and one ULP-cow, a number of pure cultures were isolated by anaerobic culture techniques and the required quantity was grown in anaerobic broth cultures (BRYANT and BURKEY 1953 a, b). The isolated bacterially pure cultures were not identified. For amino acid analyses, $100 \mathrm{mg}$ microbial protein was hydrolysed and the amino acids were determined as reported earlier (Syväoja 1971) using a Bio Cal (Model BC 201) automatic amino acid analyser.

The in vitro digestibility experiments with bacteria, protozoa and lyophilized egg protein, using pepsin-pancreatin were performed with methods of AKESON and Stahmann (1964) and Bergen et al. (1967). Pepsin-pancreatin digest residue indices (PPDR-I) were calculated according to the egg ratio method of Sheffner et al. (1956) as modified by Akeson and Stahmann (1964). Essential amino acid indices (EAA-I) were calculated according to OSER (1951). Digestion coefficients were estimated by modifying the pepsin digestibility method for proteins (BERGEN et al. 1968) according to the formula:

Digestibility $=\frac{\text { total amino acid }- \text { insoluble amino acid. }}{\text { total amino acid }}$

\section{Results and Discussion}

Table 1 shows the amino acid compositions of the rumen bacteria and protozoa of 0 -, ULP- and NorP-cows, and those of the pure cultures isolated from the rumen of a 0 -cow and a ULP-cow. The amino acids were calculated as percentages of the total amino acid of the hydrolysate, being means of several determinations. On pure cultures two determinations were made. The results were calculated with the exclusion of tryptophan, which is decomposed in acid hydrolysis.

With regard to the essential amino acids (EAA), there were statistically significant differences with valine, methionine, isoleucine, leucine, phenylalanine and lysine $(\mathrm{P}<0.05)$; the protozoa contained more cystine, isoleucine, leucine, phenylalanine and lysine and less valine and methionine than the bacteria.

Using a variance analysis and Tukey's t-tests it was found that the rumen bacteria of 0 - and NorP-cows did not differ with respect to any amino acid. The rumen bacteria of the ULP-cow differed from those of the other two with respect to threonine and arginine $(\mathrm{P}<0.05)$ and further from those of the 


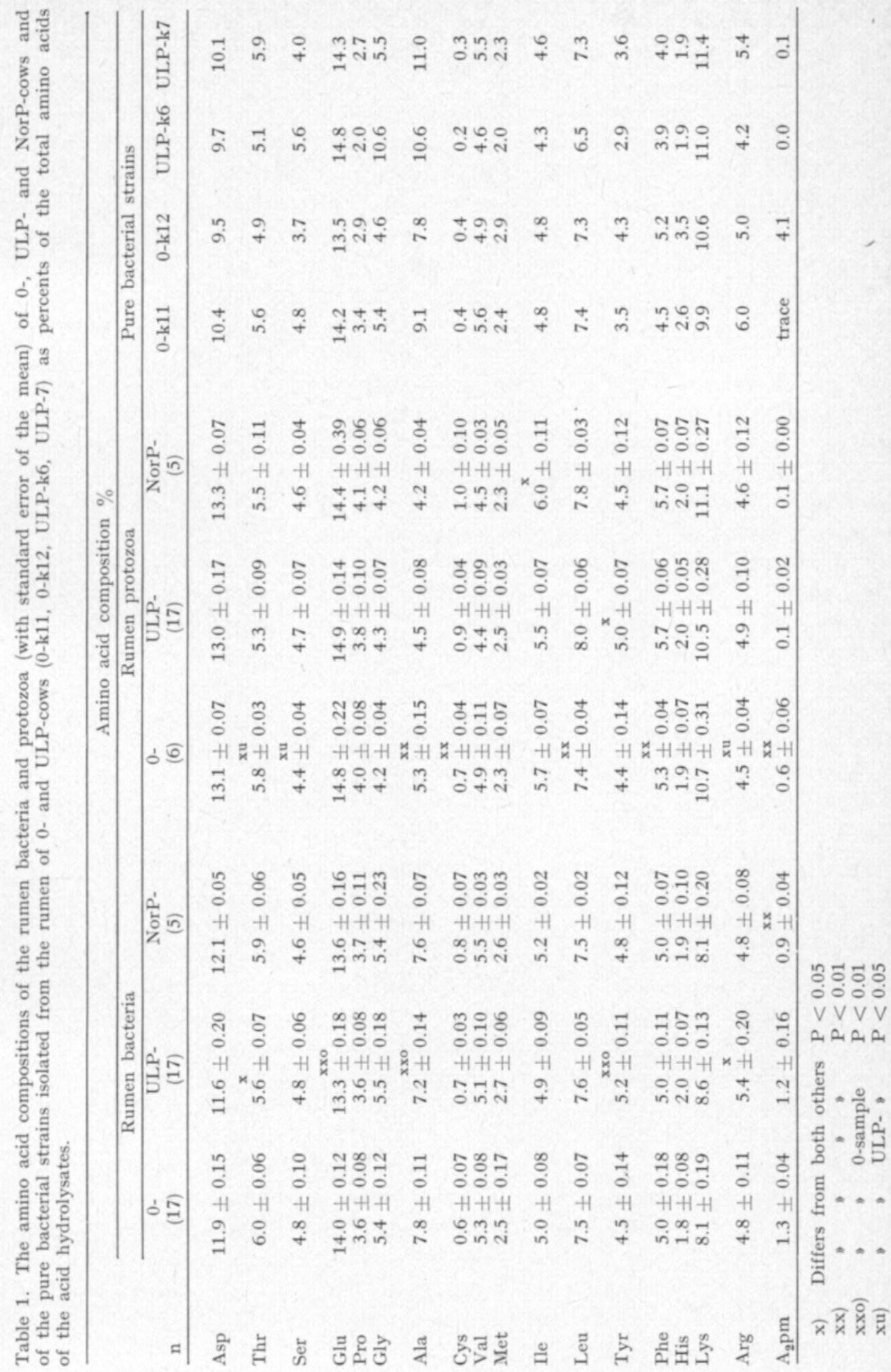


0 -cow with respect to glutamic acid, alanine and tyrosine $(\mathrm{P}<0.01)$. The amino acid compositions of samples taken at different times showed relatively small differences, as can be seen from the low standard error of the mean. The amino acids of bacteria showed thus very slight deviations, though the feed - particularly the nitrogen feed - differed very much. Similar results have been reported by several other scientists (WELler 1964, Hoeller and HARMeyer 1964, Bergen et al. 1968, Ibrahim and Ingalls 1972, Burris et al. 1974). Williams and Dinusson (1973) found only slight differences in the amino acid composition of microbial protein, independent of whether or not the microbial population contained ruminal ciliated protozoa. The amino acid compositions of the microbial samples taken at various times differed much more than in our experiments, either at different times on the same feed or on different feeds.

While the rumen bacterial proteins of cows on different feeds showed no real difference with regard to their amino acid compositions, there were definite differences in the amino acid compositions of the isolated bacterial cultures. As regards the EAA, the greatest differences occurred in the amounts of methionine and histidine. The proportion of methionine of the total amino-acid varied from 2.0 to $2.8 \%$, and that of histidine from 1.9 to $3.5 \%$. Corresponding differences were found by PURSER and Buechler (1966) in the amino acid compositions of 22 different bacterial pure cultures. The protein of different bacterial strains contained, for example, $4.7-11.4 \%$ valine, $7.3-14.9 \%$ lysine, $1.9-2.5 \%$ histidine and $1.3-2.9 \%$ methionine. However, the investigators regarded the differences as insignificant.

The protozoa differed only with respect to isoleucine and tyrosine $(\mathrm{P}<$ 0.05 ) in the rumen of ULP- and NorP-cows. In contrast, the amino acid composition of the rumen protozoa of the 0 -cow differed from that of the other two with respect to alanine, cystine, leucine and phenylalanine $(\mathrm{P}<0.01)$ and from that of the ULP-cow also with respect to threonine, serine and arginine $(\mathrm{P}<0.05)$. The differences may be due to the fact that the protozoal preparations were not entirely devoid of bacteria. The presence of diaminopimelic acid was evidence of bacterial contamination, or indicated the amount of bacterial protein just consumed by the protozoa. The differences could also arise from different species of protozoa. Hoeller and HARMeyer (1964), Poley (1965) and Williams and Dinusson (1973) found interspecies differences in the amino acid composition of protozoa. However, the protozoa isolated from the rumen contained many species, so that species differences could not be established. MäKINEN (1972) observed that the rumen of 0-cows contained a much greater bacterial population than ULP- and NorP-cows. In the rumen of ULP-cows the number of protozoa was larger than in that of NorP-cows, and the rumen of 0 -cows was entirely devoid of protozoa. However, we did find protozoa in the rumina of two 0 -cows occasionally. It was interesting to observe that the protozoa seemed to be of the same species, as examined with a microscope, with the exception of a few small diplodinia. It was difficult to identify the species on the basis of the literature.

In the rumen of the ULP-cow both the number and the range of species of protozoa were larger than in that of the NorP-cow. 


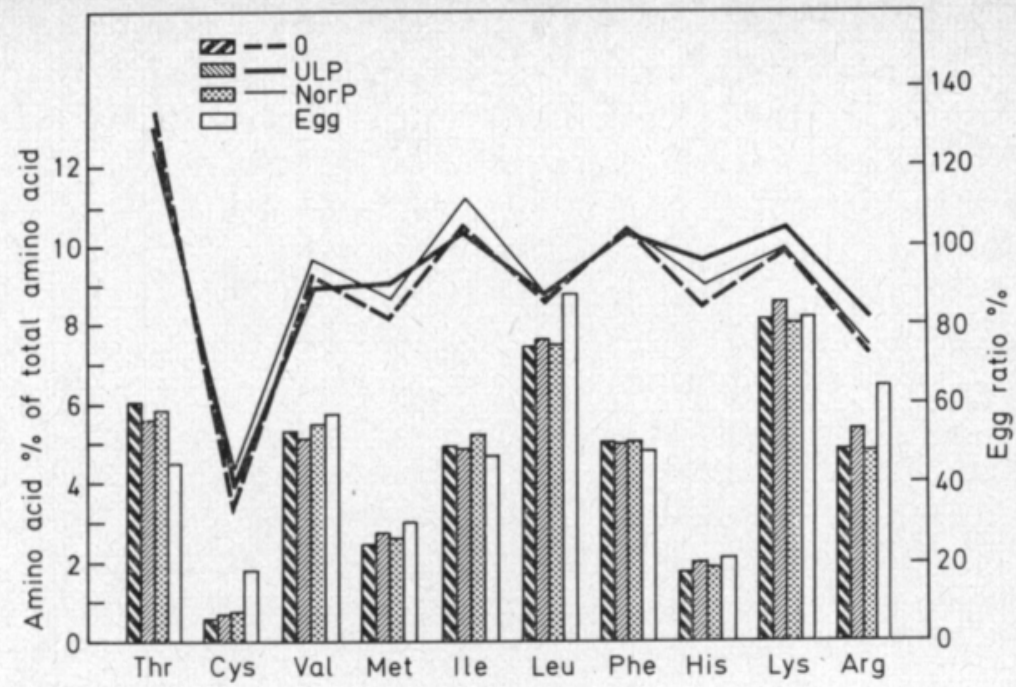

Fig 1. Essential amino acid composition of acid hydrolysates of egg and rumen bacteria plus nutritional egg ratio curve of rumen bacteria of 0 -, ULP- and NorP-cows.

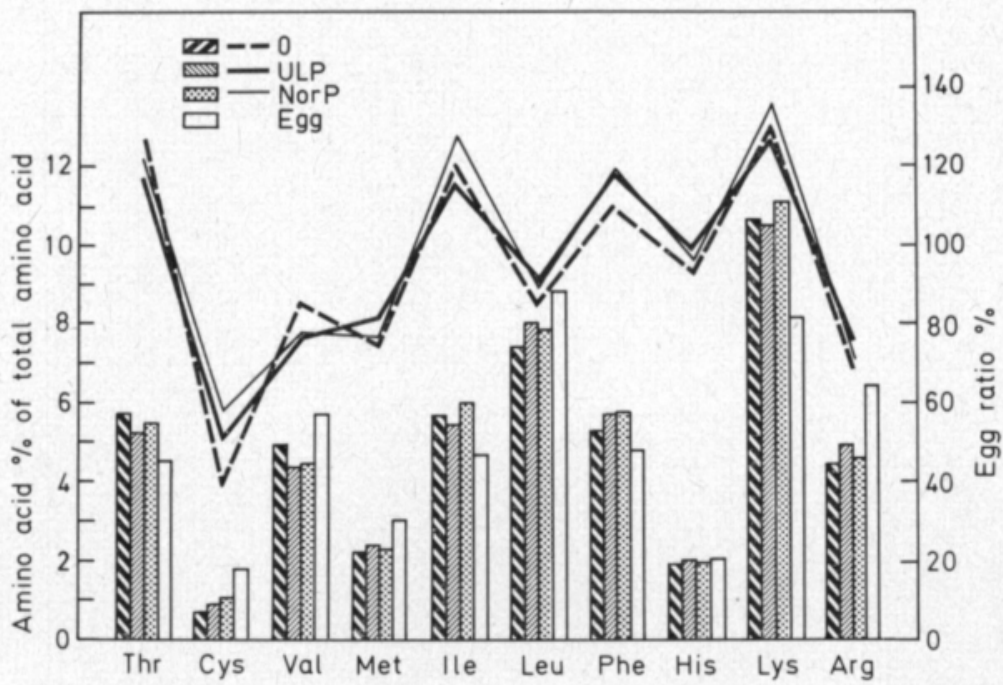

Figure 2. Essential amino acid composition of acid hydrolysates of egg and rumen protozoa plus nutritional egg ratio curve of rumen protozoa of 0 -, ULP- and NorP-cows.

Figure 1 shows the EAA of the rumen bacteria of the cows on different feeds and those of egg, as well as the ratio between the EAA of bacteria and egg (egg ratio). The corresponding results for protozoa are presented in Figure 2. When comparing the quality of the total protein on the basis of the EAA, it was observed that the bacterial protein contained less cystine, arginine, 
leucine, methionine, histidine and valine than the egg protein. The egg ratio of methionine and histidine of the rumen bacteria and protozoa of the 0-cow was lower than that of ULP- and NorP-cows. The amounts of methionine and histidine did not, however, differ statistically in different rumina. The EAA-I of the rumen bacteria of ULP- (91.3) and NorP-cows (89.8) did not differ much; similar results were obtained with the protozoa (ULP 89.3, NorP 88.3). Neither were the EAA-I of the bacteria and protozoa of the 0 -cows (87.8 and 87.0) significantly lower than those of ULP-and NorP-cows. The amino acid composition of the pure cultures isolated from the rumina was different and thus also the EAA-I varied more $(79.7-90.6)$ than that of the other bacteria (87.8-91.3).

The EAA-I and chemical score are generally used indices when the nutritional quality of protein is studied. Both are based on the total amino acid composition, and do not thus indicate possible variations in digestibility and the real intake of amino acids. In general the chemical score underestimates the biological value of a protein, while the EAA-I overestimates it. The pepsinpancreatin in vitro digestibilities are shown in Table 2 . With all feeds the in vitro digestibility of protozoa was higher than that of bacteria. McNaught et al. $(1950,1954)$ found in their in vivo experiments that the microbial preparations which contained protozoal protein had a higher nutritive value than bacterial protein. The digestibilities of bacteria and protozoa were 74 and $87 \%$.

VERMA and Singh (1977) determined the digestibility of the protein of mixed labelled whole rumen bacterial cells in buffaloes and in goats. The radioactivity excreted in the faeces was measured. The digestibility of the

Table 2. EAA-indices, in vitro digestibilities and PPDR-indices of the rumen bacteria and protozoa of ULP-, NorP-and 0 -cows, and of some pure bacterial strains $(0-\mathrm{k} 11,0-\mathrm{k} 12$, ULPk6, ULP-k7).

\begin{tabular}{lccc}
\hline Sample & EAA-I & Digestibility & PPDR-I \\
\hline ULP- bacteria & 91.3 & $76 \pm 2.6$ & 77.1 \\
NorP- & 89.8 & $67 \pm 2.6$ & 70.9 \\
0- & 87.8 & $63 \pm 2.8$ & 65.9 \\
ULP- protozoa & 89.3 & $78 \pm 0.9$ & 76.3 \\
NorP- & 88.3 & $90 \pm 0.3$ & 98.3 \\
& & & \\
0- & 87.0 & $73 \pm 0.6$ & 67.2 \\
0-k11 bacteria & 90.6 & 48 & 48.5 \\
0-k12 & 89.6 & 81 & 85.4 \\
ULP-k6 & 79.7 & 47 & 46.9 \\
ULP-k7 & 85.7 & 76 & 72.4 \\
\hline
\end{tabular}

xu Differs from the ULP-sample, but not from the NorP-sample $\mathrm{P}<0.05$

$\mathbf{x x}$ Differs from both others $\mathrm{P}<0.01$. 
bacterial protein was 81.7 and $87.2 \%$ in goats and buffaloes respectively. Streptococcus bovis was highly digestible (91-96.9\%).

The digestibility of protozoa with NorP- and ULP-feeds was 90 and $78 \%$, the difference being statistically significant $(\mathrm{P}<0.01)$. The digestibility of the protozoa of the 0 -cows was $73 \%$, but owing to its particular nature it cannot perhaps be compared with the above figures. The digestibility of the rumen bacteria $(63 \%)$ differed statistically from the corresponding digestibility of the ULP-samples $(76 \%)(\mathrm{P}<0.05)$, but not from those of the NorPsamples $(67 \%)$. The digestibility of the rumen bacteria with different 0 -cows varied between 57 and $67 \%$. The individual differences were even greater in the in vitro digestibility of the different bacterial species. We succeeded in isolating from the rumen of a 0 -cow and a ULP-cow bacterial species which had either good (76 and $81 \%$ ) or poor (47 and $48 \%$ ) in vitro digestibility.

BERGEN et al. (1967) studied the quality of the protein of 14 different bacterial strains using the in vitro pepsin-pancreatin digestibility method. They found that in spite of the similar amino acid composition of the bacterial strains the quality of their protein was different. The digestibility of cellulolytic strains was lower $(69.4 \%)$ than that of noncellulolytic $(77.9 \%)$. The authors emphasised that the differences could be due either to differences in the total digestibility or to the liberation of single amino acids from bacterial protein.

According to our observations the digestibility of single amino acids of bacterial protein did not differ from the total digestibility, with the exception of diaminopimelic acid. $80-90 \%$ of this amino acid occurred in the indigestible residue after pepsin-pancreatin digestion. Also the liberation of glycine and alanine from bacterial protein was 3-10\% units lower than that of the total amino acids, independent of the feed. The much larger number of bacteria in the rumen of 0 -cows compared with those of ULP- and NorP-cows compensates in this way for the lower digestibility of bacterial protein in 0-cows.

BURris et al. (1974) found, however, that the liberation of threonine, serine, glutamic acid, valine, methionine, phenylalanine and lysine, and also that of total amino acids, was influenced by the protein feed of the animal. The essential amino acids were more completely released from bacterial protein upon in vitro digestion than were the nonessential amino acids. The release of lysine was found to vary to a greater extent than the other amino acids. Lysine had a significantly greater release rate from bacteria obtained from steers fed soybean meal than from steers fed fishmeal. Also BERGEN et al. (1968) studied the effect of different feeds on the in vitro digestibility of rumen bacteria and protozoa. They found that the bulk amino acid composition and the protein quality of the microbial preparations were not affected by change of ration. Only on one feed (semi-purified diet containing urea) out of four was the digestibility of protozoa and bacteria + protozoa statistically significantly lower $(\mathrm{P}<0.15)$. The in vitro digestibility of bacteria varied from 64.7 to $70.1 \%$ and that of protozoa from 75.8 to $84.7 \%$ on four different feeds. The authors emphasized, however, that had the number of animals been greater in the feed groups the large individual differences would have been minimized and the numerical differences might have been significant. In our 
experiments as well the number of animals was too small. It was also unfortunate that we could not obtain rumen fluid from the NorP-cow otherwise than at slaughter, since the stress before slaughtering might have affected the microbial population in the rumen.

Protein quality was compared also by determination of the pepsin-pancreatin-digest-residue index. SHEFFner et al. (1956) developed the pepsindigest-residue amino acid index (PDR-I) which combines the pattern of EAA released by in vitro pepsin digestion with the amino acid pattern in the remainder of the protein. They found that PDR-I was closely correlated with the net protein utilization value of a variety of proteins. Akeson and Stahmann (1964) included a pancreatin digestion after a pepsin digestion in their tests and found that the PPDR-I gave a higher correlation with the biological value than the chemical score or the EAA-I.

The PPDR-I are presented in Table 2. They were calculated with the exclusion of tryptophan. According to the tests of Akeson and Stahmann (1964) the omission of tryptophan did not affect the results unless the sample under study contained very little tryptophan or none at all. The PPDR-I of the rumen bacteria of the ULP-cow was higher (77.1) than that of NorP(70.9) and 0-cows (65.9). The PPDR-I of protozoa was 98.3 (NorP), 76.3 (ULP) and 67.2 (0-cow). When the EAA-I and PPDR-I of bacteria and protozoa were compared it was found that the EAA-I varied much less on different diets and with different single cows. This was to be expected, of course, since the amino acid compositions differed only slightly. Also EAA-I and PPDR-I did not give quite the same order with regard to quality, but the digestibility coefficient and PPDR-I did. The PPDR-I of bacteria, protozoa and all samples were well correlated with the digestibility coefficient $(r=0.97,0.99$ and 0.97), but weaker with EAA-I ( $\mathrm{r}=0.85,0.36$ and 0.32). BERGEN et al. (1967, 1968) determined the PPDR-I of different bacterial species. The values varied considerably with different bacterial strains (49.7-80.7). However, the authors did not find any differences when they compared the PPDR-I of the rumen bacteria $(71.3-77.1)$ and protozoa $(70.9-77.1)$ of sheep on different diets.

\section{REFERENCES}

Akeson, W. R. \& Stahmann, M. A. 1964. A pepsin pancreatin digest index of protein quality evaluation. J. Nutr. 83: 257-261.

Bergen, W. G., Purser, D. B. \& Cline, J. H. 1967. Enzymatic determination of the protein quality of individual rumen bacteria. J. Nutr. 92: 357-364.

- , Purser, D. B. \& Cline, J. H. 1968. Effect of ration on the nutritive quality of rumen microbial protein. J. Anim. Sci. 27: 1497-1501.

Bryant, M. P. \& Burkey, L. A. 1953 a. Cultural methods and some characteristics of some of the more numerous groups of bacteria in the bovine rumen. J. Dairy Sci. 36: 205217.

- \& BURKey, L. A. 1953 b. Numbers and some predominant groups of bacteria in the rumen of cows fed different rations. J. Dainy Sci. 36: 218-224.

Burris, W. R., Bradley, N. W. \& Boling, J. A. 1974. Amino acid availability of isolated rumen microbes as affected by protein supplement. J. Anim. Sci. 38: 200-205. 
Ettala, T. \& Kreula, M. 1976. Milk production on low-protein, urea-rich feed. Acta Agric. Scand. 26: $33-39$.

Hoeller, H. \& Harmeyer, J. 1964. Nitrogen and amino acid content of rumen protozoa. Zentr. Vet. Med. Reihe A, Band II 3: 244.

Hungate, R. E. The rumen and its microbes. 1966. Academic Press, New York.

Iвrahim, E. A. \& Ingalls, J. R. 1972. Microbial protein biosynthesis in the rumen. J. Dairy Sci. 55: $971-978$.

McNaught, M. L., Smith, J. A. B., Henry, K. M. \& Kon, S. K. 1950. The utilization of nonprotein nitrogen in the bovine rumen. 5. The isolation and nutritive value of a preparation of dried rumen bacteria. Biochem. J. 46:32-36.

- , Owen, E. C., Henry, K. M. \& Kon, S. K. 1954. The utilization of non-protein nitrogen in the bovine rumen. 8. The nutritive value of the proteins of preparations of dried rumen bacteria, rumen protozoa and brewer's yeast for rats. Biochem. J. 56: $151-156$.

MäKıNEN, S. 1972. Aspects of the nitrogen metabolism and nutritional status of urea-fed dairy cattle. Ann. Acad. Sci. Fenn. Ser. A II Chemica, No. 165. p. 21.

OSER, B. L. 1951. Method for integrating essential amino acid content in the nutritional evaluation of protein. J. Am. Diet. Assoc. 27: 396-402.

Poley, G. E. \& Trenkle, A. H. 1963. Influence of nitrogen source on amino acid patterns in plasma and abomasal ingesta from sheep. J. Anim. Sci. 22: 1139.

PURSer, D. B. \& BUechler, S. M. 1966. Amino acid composition of rumen organisms. J. Dairy Sci. 49: $81-84$.

Sheffner, A. L., Eckfeldt, G. A. \& Spector, H. 1956. The pepsin-digest-residue (PDR) amino acid index of net protein utilization. J. Nutr. 60: 105-120.

SYväOJA, E.-L. 1971. Studies of proteins in the milk of cows on protein-free and low-protein feeds. Ann. Acad. Sci. Fenn. Ser. A II Chemica, No. 158.

Virtanen, A. I. 1963. Production der Kuhmilch ohne Protein mit Harnstoff und Ammoniumsalzen als Stickstoffquelle und gereinigten Kohlenhydraten als Energiequelle. Biochem. Z. $338: 443-453$.

- 1966. Milk production of cows on protein-free feed. Science 153: 1603-1614.

- 1967. Milk production on a protein-free and protein-poor feed. Neth. Milk Dairy J. 21: $223-244$.

- , EttalA, T. \& Mäkınen, S. 1972. Milk production of cows on purified protein free feed with urea and ammonium salts as the only nitrogen source and on nonpurified feed with rising amounts of true protein. 2nd World Congr. of Animal Feeding. Plenary sessions. General Reports. Madrid 447-474.

WARNER, A.C. I. 1955. Factors influencing numbers and kinds of microorganisms in the rumen. In Physiology of Digestion in the Ruminant, ed. Dougherty, R. W. Butterworths, Washington D. C.

WELLER, R. A. 1957. The amino acid composition of hydrolysates of microbial preparations from the rumen sheep. Aust. J. Biol. Sci. 10:384-389.

Verma, D. N. \& Singh, U. B. 1977. Digestibility of rumen bacterial cell proteins in buffaloes and goats. J. Agric. Sci. 88: 237-239.

Wrlliams, P. P. \& Dinusson, W. E. 1973. Amino acid and fatty acid composition of bovine ruminal bacteria and protozoa. J. Anim. Sci. 36: 151-155.

Ms received February 19, 1979. 


\title{
Runsaasti ureaa saaneiden lehmien pötsin mikrobiproteinin laadun määrit- täminen in vitro-kokeilla
}

\author{
Eeva-Lissa Syväoja ja Matti Kreula \\ Biokemiallinen Tutkimuslaitos, Kalevankatu 56 B, 00180 Helsinki 18
}

Ureaa ja ammoniumsuoloja ainoana (0-lehmät) tai osittaisena (ULP-lehmät) typenlähteenään saaneiden samoinkuin normaalia proteiiniravintoa saaneiden (NorP-lehmät) lehmien pötsin bakteereiden ja prototsoien aminohappokoostumus, välttämättömien aminohappojen indeksi (EAA-I) sekä bakteeri- ja prototsoaproteiinin pepsiini-pankreatiini in vitro sulavuus ja pepsiinipankreatiini sulavuus jäännös indeksi (PPDR-I) määritettiin.

Pötsin bakteereiden aminohappokoostumukset osoittivat varsin vähäisiä eroja, vaikka ruokinta oli hyvinkin erilainen. Pötsistä eristettyjen bakteeripuhdasviljelmien aminohappokoostumukset erosivat toisistaan jonkin verran.

ULP- ja NorP-lehmien pötsin prototsoat erosivat aminohappokoostumukseltaan vain isoleusiinin ja tyrosiinin suhteen. 0-lehmien pötsistä prototsoia löydettiin vain harvoin eikä lajeja löytynyt kuin kaksi. Niiden ravinnollinen merkitys oli ilmeisesti eläimelle vähäinen.

Tutkittaessa mikrobiproteiinin ravitsemuksellista laatua aminohappokoostumuksen perusteella todettiin, että bakteerien EAA-I:t eivăt eronneet toisistaan merkittävästi. Myöskään prototsoien EAA-I:t eivăt eronneet toisistaan.

Prototsoien pepsiini-pankreatiini in vitro sulavuus osoittautui kaikilla ruokinnoilla korkeammaksi kuin bakteerien. Prototsoien sulavuudet olivat NorP- ja ULP-ruokinnoilla 90 ja $78 \%$, jotka arvot erosivat toisistaan tilastollisesti merkittävästi.

0-lehmien pötsin bakteerien in vitro sulavuus (63\%) poikkesi ULP-näytteiden vastaavasta sulavuudesta $(76 \%, \mathrm{P}<0,05)$, mutta se ei eronnut NorP-näytteiden sulavuudesta $(67 \%)$. Yksittäisten aminohappojen sulavuus diaminopimeliinihappoa, glysiiniä ja alaniinia lukuunottamatta ei poikennut aminohappojen kokonaissulavuudesta. Moninkertainen bakteerien lukumäärä 0-lehmien pötsissä verrattuna ULP- ja NorP-lehmien pötseihin kompensoi bakteeriproteiinin huonompaa sulavuutta ensinmainitulla ruokinnalla.

Sekä bakteerien että prototsoien PPDR-indeksit korreloituivat hyvin sulavuuden kanssa. ULP-ruokinnalla pötsin bakteereiden PPDR-I $(77,1)$ osoittautui korkeammaksi kuin NorP$(70,9)$ ja 0-ruokinnalla $(65,9)$. Prototsoien PPDR-indeksit olivat 98,3 NorP- ja 76,3 ULPruokinnalla. 